\title{
Komentarz do proroka Jonasza tegoż Mar-Efrema', dosłowny, a niekiedy mistyczny
}

Jonasz był ze wsi Anarin. Gdy powrócił po prorokowaniu Niniwitom, wziąwszy matkę swoją ${ }^{2}$, przeniósł się do ziemi pokolenia Chernachitów, które należało do Tyru. Mówił on bowiem: „W ten sposób uchodzę hańbie z powodu mojego oszukiwania w przepowiadaniu wobec Niniwitów".

\section{Rozdział I}

1. I było słowo Pana do Jonasza, syna Mattaja: Powstań, idź do Niniwy, wielkiego miasta. Jonasz prorokował Ezechiasza, przed tym jak dom Sennacheryba zstąpił i uderzył na Jerozolimę. Powstań, idź do Niniwy. Pan bowiem chciał posłać go do Niniwy z dwu powodów. Po pierwsze, aby przez jego przepowiadanie nawrócić Niniwitów, chociaż byli poganami i nieznającymi Pana, do czczenia Pana, aby - powiadam - gdy usłyszą o całkowitym zniszczeniu ${ }^{3}$ ich i ich miasta, zostali ogarnięci strachem przed jego przyszłym unicestwieniem i nawrócili się do czczenia Pana. Po drugie, aby zawstydzić Izraela przez to, że narody, które nie znają Pana ani nie słyszały Prawa Mojżesza, ani nie widziały potężnych dzieł jak oni, nawróciły się dzięki przepowiadaniu Jonasza i poznały Boga. Miasto Niniwa jest zatem figurą tego świata.

3. Prorok Jonasz uciekł zaś do Tarszisz. Jonasz uciekał do Tarsu z tego powodu, że w swojej prostocie myślał, że w Jerozolimie jest święte miejsce Boga, a także nie chciał iść do Niniwy, aby wzywać do nawrócenia, by w ten sposób dać do zrozumienia, że prorocy nie zostali posłani do narodów. Cierpiał zaś i przykro mu było, ponieważ widział, że łaska proroctwa przechodzi na obce narody, a Izrael jest jakby wypędzony ze swojego domu.

1 Rzeczownik more’ oznacza „pan”. W tradycji chrześcijańskiej zaczął funkcjonować jako określenie „święty”, a także tytuł biskupów, urzędników itp. W Pešitcie odnosi się do Boga, analogicznie do greckiego Kyrios.

2 Tradycja żydowska widzi w Jonaszu syna wdowy z Sarepty wskrzeszonego przez Eliasza (por. 1 Krl 17,17-24). Wspomnienie w tym komentarzu o matce Jonasza może być śladem tej tradycji.

3 Dosł. ,zniszczeniu i spustoszeniu”. To wyrażenie można zinterpretować jako hendiadys. 
4. I nastała burza na morzu, aż statek zwracał się ku rozbiciu. Jonasz natomiast zszedł do wnętrza statku i spał. Marynarze widzieli, że morze w jednym czasie srożyło się i uciszało. Srożyło się przeciwko nim, a uciszało dla innych.

7-14. I rzucali losy i padł los Jonasza... Oto morze następuje i sroży się przeciwko nam. Mówili więc marynarze do siebie nawzajem: Rzucajmy losy, abyśmy poznali (przez kogo) to zło przyszło na nas 4 . I rzucili losy. A gdy los padt na Jonasza, powiedział im: Weźcie mnie i rzućcie do morza. I morze uspokoiło się. A owi mężowie przerazili się i ofiarowali ofiary i ślubowali śluby. I zawołali marynarze do Pana, mówiąc: Panie, obyśmy nie zginęli z powodu tego człowieka. To, że marynarze zwrócili się do Pana i prosili, aby nie zginęli z powodu Jonasza i nie zostali uznani za winnych z powodu jego śmierci, jest figurą świętych proroków. Ci przecież, kiedy prorokowali na temat męki i śmierci Chrystusa, prosili, aby lekceważący to nie byli brani pod uwagę, ponieważ pisali o śmierci Boga. To natomiast, że Jonasz powiedział: Weźcie mnie i wyrzućcie do morza, jest wielką tajemnicą. Uczy przecież Emmanuela przyjmować na siebie cierpienia z własnej woli. To w końcu, że morze uciszyło się po swoim wzburzeniu, kiedy tylko został do niego wrzucony Jonasz, oznacza, że Duch umilkł dopiero po śmierci Emmanuela.

\section{Rozdział II}

1. Wielka ryba, która pożarła Jonasza, jest figurą śmierci, która pochłonęła naszego Pana. Był Jonasz we wnętrznościach ryby przez trzy dni. To zapowiada, że Pan nasz przebywał we wnętrznościach ziemi przez trzy dni i trzy noce ${ }^{5}$. Przebył żywy Jonasz we wnętrznościach ryby, także żywy pozostał Pan nasz, nawet po tym, jak został położony w świętym grobie.

2. (Jonasz) modlił się w brzuchu ryby. To zapowiada, że również Mesjasz ze swoim Ojcem rozmawiał, kiedy był zamknięty w Szeolu. Był przecież żywy i silny, i odtąd obdarzony mocą wskrzeszania. Kiedy mówi się, że droga do Niniwy trwa trzy dni, nie oznacza to, że miasto leży w odległości trzech dni drogi, ale że całe miasto usłyszało w przeciągu trzech dni głoszenie Jonasza. Pierwszego dnia usłyszał je lud, drugiego - przywódcy, a trzeciego król ze wszystkimi swoimi sługami. Innymi słowy: pierwszego dnia usłyszeli doskonali, drugiego - sprawiedliwi, a trzeciego - pokutujący. Niniwa jest figurą świata, a Jonasz wyobraża nam Syna Boga, który przyszedł, aby pojednać świat ze swoim Ojcem, i ogłosił światu zbawienie przez siebie i przez uczniów swoich. Stąd najpierw usłyszeli całą Ewangelię i jej nakazy wypełnili doskonali, którzy nie byli pochłonięci sprawami ziemskimi, ani duszy swojej światu nie oddali w niewolę, ani nie podążali

\footnotetext{
4 Zmieniony porządek wersetów względem tekstu biblijnego.

5 Por. Mt 12,40.
} 
za jego przyjemnościami. W drugiej kolejności to ci, którzy zostali wprzęgnięci w przyziemne obowiązki przez troskę o żonę i dzieci. Gdy Ewangelia Chrystusa została im przyniesiona, przyjęli ją z wiarą i postępowali sprawiedliwie w modlitwie, poście i jałmużnie, które ich trud zrodził. W trzeciej kolejności są ludzie, czy to poganie, czy Żydzi, czy inni, którzy uwierzyli w Mesjasza i żyli jako prości i niewykształceni na tym świecie.

3-5. Zawołałem do Pana $w$ udręce mojej i odpowiedział mi. Ta modlitwa, którą wypowiedział Jonasz w brzuchu ryby, była modlitwą z proroctwem. I odpowiedział, i uslyszał głos mój. To była modlitwa. Natomiast słowa: Znów ujrzę twoja świątynię świętą, były proroctwem.

\section{Rozdział III}

4. I zaczą Jonasz wstępować do miasta Niniwy i przez trzy dni ogłaszał, i mówit: „Od teraz za czterdzieści dni Niniwa zostanie zniszczona”. Po grecku zaś powiedział: Od teraz za trzy dni Niniwa zostanie zniszczona. A prawdą jest jedno i drugie. Tak bowiem zostało napisane w pismach hebrajskich: Zaczą Jonasz iść do miasta Niniwy przez czterdzieści dni. Wiadomo jest, że rzecz to niemożliwa, aby to miasto leżało w odległości czterdziestu dni drogi i aby Jonasz pozostawał w nim przez czterdzieści dni, dopóki nie zobaczy, co się stanie. Gdzie bowiem Jonasz mógłby zatrzymywać się na noc? A poza tym, kiedy skwar słońca męczył głowę proroka, młoda rozłożysta roślina ${ }^{6}$ wzniosła się ponad jego głową, osłaniając go. Gdyby zatem przez czterdzieści dni dynia pozostawała, żeby swoim cieniem chronić Jonasza od skwaru, to w jaki sposób mógłby powiedzieć, że rozłożysta roślina jednej nocy ukazała się i jednego dnia znikła, skoro przez czterdzieści dni prorok oczekiwał, żeby zobaczyć, co się stanie? Słusznie zatem Siedemdziesięciu mężów przetłumaczyło: Od teraz za trzy dni Niniwa zostanie zniszczona. Podczas gdy owe czterdzieści dni oznacza długość drogi od tego, jak Jonasz został przez rybę zwymiotowany, aż dotarł do Niniwy, to natomiast od teraz za trzy dni i Niniwa zostanie zniszczona wskazuje nam jego przepowiadanie dla tego miasta i podaje określony czas skruchy dla Niniwy. I w ten sposób oba zostały przyjęte: „,zterdzieści” o długości drogi, „trzy” o przepowiadaniu, o łaskawości. Ponownie: Od teraz za czterdzieści dni Niniwa zostanie zniszczona, jakby w proroctwie mówi, że ona zwróci się w kierunku zła.

Dopóki nie zobaczy, co się stanie. Aquila i Symmach tak przetłumaczyli: Od teraz za czterdzieści dni Niniwa zostanie zniszczona. Gdzie zatem Jonasz mógłby zatrzymać się na noc? Skąd miałby wiedzieć, że (Niniwa) nie zostanie zniszczona. Dopóki zaś słońce skwarem dokuczało jego głowie, dopóty wschodziła

6 Tłumaczenie przypuszczalne. Syryjski rzeczownik qar’o' nie jest jednoznaczny. Najprawdopodobniej jest to nazwa własna rozłożystej rośliny dyniowatej. 
dynia i cieniem go osłaniała. Jeżeli przez czterdzieści dni pozostawałby w ten sposób, tak że cieniem jej był osłaniany od skwaru, dlaczego powiedział, że dynia powstała jednej nocy i jednej nocy znikła, skoro przez czterdzieści dni trwał w oczekiwaniu na to, co się miało stać? Słusznie zatem owych Siedemdziesięciu dwóch jest odczytywanych: Od teraz za czterdzieści dni Niniwa zostanie zniszczona. Określają zatem - jak uważamy - że owe „czterdzieści” mówi o drodze i kiedy interpretują to wyrażenie o czasie i długości drogi, węzeł słów rozwiązują i objaśniają powiedzenie „trzy dni”.

Król zaś, który w Niniwie zostawił koronę swoją i przywdział wór, jest dla nas figurą umysłu, który to przez Ewangelię Pana naszego wyzbył się wyniosłości i przywdział pokorę ze względu na swoje poprzednie występki.

\section{Rozdział IV}

2-3. O Panie, czyż to nie było moje słowo, że dotąd jestem na mojej ziemi? Dlatego najpierw uciekałem do Tarszisz, ponieważ lepiej byłoby mi umrzeć niż żyć. Te słowa powiedział prorok, ponieważ wiedział, że w obliczu całkowitej zagłady Niniwy, co przez niego samego było obwieszczone, mieszkańcy Niniwy będą pokutować i Bóg z powodu swojego miłosierdzia przyjmie ich pokutę i przebaczy im. „Ja, powiada, będę sobie fałszywym prorokiem i dlatego uciekałem do Tarszisz. Trzeba więc, bym raczej umarł niż przepowiadał kłamstwo".

6-7. Następnie Pan rozkazał rozłożystej roślinie, która wyrosła i wzniosła się ponad Jonasza. Następnego dnia zaś Pan rozkazał robakowi o brzasku, aby uszkodzit rozłożysta roślinę, a on ja popodgryzał. Wtedy zapłonęło słońce nad głowa Jonasza. Na podstawie tego zdarzenia Jonasz przepowiedział zniszczenie Niniwy, wyruszył i usiadł poza miastem, oczekując strasznego zniszczenia, którym groził miastu. Miasto zaś dzięki swojej pokucie rozwiązało dawny spór i uczyniło daremnym, i pogodziło się z Bogiem. O, łaskawości Boga! Gdy zobaczył, że Jonasz jest smutny z powodu odłożonej zagłady i zrozumiał, że serce jego oczekuje zniszczenia mieszkańców Niniwy, aby jego proroctwo nie okazało się kłamstwem, postanowił ofiarować mu pocieszenie, wydawszy polecenie, aby rozłożysta roślina wyrosła i szybko wzeszła, i cień zapewniła nad głową proroka, aby ten z powodu skwaru słońca nie cierpiał. Gdy zaś prorok wielce się uradował, natychmiast tego samego dnia Pan rozkazał robakowi, który korzenie młodej rozłożystej rośliny popodgryzał, i natychmiast wiatr suchy dotknął rozłożystą roślinę i niszcząc jej piękno, wysuszył ją. Radość zaś, której doznawał Jonasz za sprawą cienia owej rośliny, gdy wzeszło słońce i z przyzwyczajenia piekło przenikliwiej ponad głową proroka, zamieniła się w smutek. Pan zaś wtedy znalazł okazję, aby wejść w spór z Jonaszem: „Ty, Jonaszu, z powodu zniszczenia marnej roślinki, która bez twojego trudu i troski wzrosła i powstała, która tak szybko uschła jak wzrosła, to wszystko znosisz, ja zaś, który w mojej dobroci stworzyłem 
ludzi i strzegę ich moją opatrznością i z troską udzielam im pokarmu życia, czy nie trzeba było, abym im pokutującym przebaczył i wykazał się cierpliwością wobec grzeszących z dnia na dzień oczekując, że będą pokutować. Dlaczego zatem powinienem zniszczyć miasto pełne ludzi, którzy z powodu twojego proroctwa naprawili swoje złe zwyczaje i zaczęli pokutować? Powinieneś zaś się rozweselić, ponieważ dzięki twojemu proroctwu mieszkańcy Niniwy odstąpili od błędu, jako że z ich zguby nic dobrego by nie wynikło". Pan uspokoił tymi i innymi słowami proroka przejętego smutkiem, że jego proroctwo okaże się kłamstwem.

To zacienione miejsce, które uczynił sobie prorok Jonasz poza miastem, symbolizuje dla nas synagogę. To, że synagoga była nazywana zacienionym miejscem, poświadcza Izajasz: Stała się zaciemniona córka Syjonu tak jak chatka w winni$c y^{7}$. Młoda rozłożysta roślina jest figurą ludu, pośród którego prorocy siedzieli i doznawali radości.

Całość komentarza do Jonasza ${ }^{8}$.

Tłumaczenie:

Mariusz Szmajdziński

7 Por. Iz 1,8 wg Peš.

8 Tłumaczenia tekstu dokonano na podstawie Sancti Ephraem Syri Hymni et Sermones quos e Codicibus Londinensibus, Parisiensibus et Oxoniensibus descriptos, edidit, latinitate donacvit, variis lectionibus instruxit, notis et prolegomenis illustravit Thomas Josephus Lamy, tomus II, Mechliniae M.D.CCC.LXXXVI., 229-246. 